\title{
EMBODYING POPULAR PIETY: CODE OF CONDUCT AND DEATH ANNIVERSARY IN THE TARĪQAH QĀDIRIYYAH WA NAQSHBANDIYYAH
}

\author{
Asfa Widiyanto* \\ State Institute for Islamic Studies (IAIN) Salatiga \\ Email: widiyanto_asfa@daad-alumni.de
}

\begin{abstract}
This paper investigates how the code of conducts and devotion to the leaders develop in the Sufi orders, and how these shape the notion of "popular piety", by paying a particular attention to the Tarīqah Qàdiriyyah Wa Naqshbandiyyah (TQN) in Mranggen, Central Java. This article starts with highlighting the ways in which the leaders of the TQN prescribe a set of rules of conduct, and how this set of rules is grounded on "web of beliefs and practices" of the community in question. It also delves into the ways in which the followers acknowledge this code of conduct, on the one hand, and respect their living and death leaders, on the other hand. It argues that code of conduct and leaders' death anniversary contribute to the moulding of popular piety within the Muslim community, in general, and among members of the TQN in particular.
\end{abstract}

Keywords: code of conduct, death anniversary, popular piety, web of beliefs and practices, Țarīqah Qādiriyyah Wa Naqshbandiyyah.

DOI: http://dx.doi.org/10.20414/ ujis.v20i2.979

*My thankfulness goes to Prof. Dr. Stephan Conermann and Prof. Dr. Eva Orthmann for their invaluable comments and suggestions to the earlier versions of this paper. My gratitude also goes to the reviewers and editors of this current journal. 


\section{Introduction}

SUFISM is reckoned as playing a significant part in Islamisation. The nine saints (Walisongo), who are believed to be prominent figures in disseminating the Islamic faith throughout the Archipelago, were considered as Sufis. A number of specialists ${ }^{1}$ explain that it was the teaching of Sufism - which is in accordance with local tradition - that has attracted the people of the Archipelago to embrace the Islamic faith.

The phenomenon of the dissemination of Islam via Sufism, in particular after the thirteenth century, was in line with the common state of the Muslim world at that time. For some scholars, since the Persian scholar Abū Hammad ibn Muhammad al-Ghazāī (1058-1111), it is Sufism that has influenced the Muslim world more than anything else. In the opinion of some scholars, the overthrow of Baghdad in 1258 likewise marked the prevalence of the Sufi orders throughout the Muslim world, since among others the Sufi missionaries were compelled to depart from Baghdad and to look for other places to propagate their respective doctrines $^{2}$ - and this, according to some scholars, fostered the so-called "internationalisation of Sunni Islam". ${ }^{3}$ The return to Sunni orthodoxy that was clearly observable after the twelfth century seems to have reached its peak during the subsequent periods, especially the seventeenth and eighteenth centuries. ${ }^{4}$

It is worth remarking, however, that the Sufi order can be regarded as a further development of Sufism embodied in the form of spiritual association in which the modes of ritual and

${ }^{1}$ Azyumardi Azra, "Opposition to Sufism in the East Indies in the Seventeenth and Eighteenth Centuries," in Islamic Mysticism Contested: Thirteen Centuries of Controversies and Polemics, ed. Frederick de Jong and Bernd Radtke (Leiden: Brill, 1999), 665.

2Zulkifli, Sufism in Java: The Role of the Pesantren in the Maintenance of Sufism in Java (Jakarta and Leiden: INIS, 2002), 7.

${ }^{3}$ Azyumardi Azra, Jaringan Ulama Timur Tengah dan Kepulauan Nusantara Abad XVII \& XVIII: Akar Pembaharuan Islam Indonesia (Bandung: Mizan, 1996), 33-6.

${ }^{4}$ Azyumardi Azra, The Origins of Islamic Reformism in Southeast Asia: Networks of Malay-Indonesian and Middle Eastern 'Ulama' in the Seventeenth and Eighteenth Century (Leiden: KITLV Press, 2004), 33. 
the relationship between the disciple and the master are prescribed. One publication ${ }^{5}$ explains that the dissemination of Islam in the Indonesian Archipelago is remarkable in the sense that the intensive process of Islamisation in this Archipelago began in the course of the thirteenth century when the tariqah was at its peak. One should note that the tariqah is the final development of Sufism.

Another study on Sufism explains that although trade was regarded as having conveyed Islam to Java, it was religious leaders (especially Sufis) and Muslim rulers who were in charge of the setting up of Islam as the religion of Java. ${ }^{6}$ Javanese people had been acquainted with the mystical tradition, and were inclined to embrace Islam because of their affinity to magical rituals and powerful mysticism which had been introduced by the Muslim mystics. ${ }^{7}$

It is of particular interest to see how the veneration and devotion to the leaders develop in the Sufi orders in the Indonesian archipelago. This article pays a particular attention to the Tarīqah Qādiriyyah Wa Naqshbandiyyah (TQN) in Mranggen, Central Java. The development and general features of the TQN will be highlighted, with a particular attention to the TQN in Mranggen, Central Java. The discussion on the notion of "popular piety" will be also provided since this will reveal us a better understanding on code of conduct and leaders' death anniversary. The discussion on leaders' death anniversary and code of conduct towards the master in the TQN constitute the main body of this paper. These two notions will be portrayed with the framework of "popular piety".

${ }^{5}$ Martin van Bruinessen, Tarekat Naqsyabandiyah di Indonesia: Survei Historis, Geografis, dan Sosiologis (Bandung: Mizan, 1998), 15.

${ }^{6}$ Mark R. Woodward, Islam in Java: Normative Piety and Mysticism in the Sultanate of Yogyakarta (Tucson: The University of Arizona Press, 1989), 54.

7Paul Michel Munoz, Early Kingdoms of the Indonesian Archipelago and the Malay Peninsula (Singapore: Editions Didier Millet, 2006), 292. 


\section{The Tarīqah Qādiriyyah Wa Naqshbandiyyah: with a particular attention to Mranggen, Central Java}

Ahmad Khatib Sambas (1803-1875) is considered as the founder of the Tarīqah Qādiriyyah Wa Naqshbandiyyah (TQN). He lived and taught in Mecca in the nineteenth century. Sambas combined the elements of both Qādiriyyah and Naqshbandiyyah. The Qàdiriyyah is one of the Sufi orders promoting the vocal recollection of God's names (dhiker jabri). The Naqshbandiyyah is one of the Sufi orders which advocate silent recollection (dhikr khafi). ${ }^{8}$

There were some main centres of the TQN in Java, particularly during the 1970s, such as the Pesantren ${ }^{9}$ Futuhiyyah Mranggen Demak under the leadership of Sheikh Muslih ibn 'Abd al-Rahman al-Maraqi (d. 1981), and the Pesantren Pagentongan Bogor under the leadership of Sheikh Tubagus Muhammad Falak. ${ }^{10}$ In this vein, we can observe the connection between pesantren and tariqah. Some pesantrens have played a significant role in developing and disseminating Sufism and tariqah. Even though we encounter such a pesantren as the Pesantren Suryalaya Tasikmalaya which is known for its being the centre for teaching and learning the tariqah.

Muslih ibn 'Abd al-Rahman ibn Qasid al-Haq al-Maraqi, the most prominent figure in propagating the TQN in Mranggen, Demak, Central Java is said to be descent of some prominent Javanese Islamic figures. It is said that his lineage reaches back to Sunan Kalijaga (b. circa 1450), one of the nine saints of Java (Walisongo). From his mother's side, he is believed to inherit a blood tie with Raden Patah (d. 1518), the king of Demak, and

${ }^{8}$ For further explanation of the type(s) of dhikr practised in the Naqshbandiyya, please see: Hamid Algar, "Silent and Vocal Dhikr in the Naqshbandi Order," in Akten des VII Konggresses für Arabistik und Islamwissenschaft (Göttingen: Vandenhoek \& Ruprecht, 1974), 39-46. See also: Isenbike Togan, "The Khafi Jahri Controversy in Central Asia Revisited," in Naqshbandis in Western and Central Asia: Change and Continuity, ed. Elizabeth Ozdalga (Istanbul: Swedish Research Institute in Istanbul, 1999), 17-46.

${ }^{9}$ The pesantren is a traditional Islamic boarding school in Indonesia.

${ }^{10}$ Bruinessen, Tarekat Naqsyabandiyah, 94-6. 
Darmo Kusumo (known as Brawijaya I, ruled Majapahit in 1447-1451). ${ }^{11}$

Muslih received his initial education at the pesantren of his father ('Abd al-Rahman ibn Qasid al-Haq), which was established around 1901. This pesantren was named after the village where it was located, namely "Pesantren Suburan Mranggen", later called "Pesantren Futuhiyyah".12

Muslih pursued his education in some other pesantrens in Java, most notably Brumbung Demak under Ibrahim Yahya, Patebon Kendal, Mangkang Kulon Semarang, Termas Pacitan, in Sarang Rembang under Zubair Dahlan, and in Lasem Rembang under Ma'sum Ahmad. ${ }^{13}$ It is quite normal for a leadership candidate of the pesantren to study in some other pesantrens, mostly the old ones, before developing his pesantren. The relationship to former teachers nevertheless remains strong. This gives an idea about the networks that have been built up among the pesantrens in Indonesia.

Martin van Bruinessen supposes that Muslih did not study in the Middle East, as many of his contemporary kyais did;14 nevertheless he wrote some books in Arabic and was respected by other kyais. ${ }^{15}$ However, van Bruinessen's supposition is somewhat contradictory to other sources. Some sources mention that Muslih studied in Mecca when he performed the pilgrimage with his teacher, Ibrahim Yahya. He studied under Yasin al-Fadani and obtained some silsilas (chains of authority)

${ }^{11}$ Team Peneliti Sejarah Seabad Ponpes Futuhiyyah Mranggen, Sejarah Seabad Pondok Pesantren Futubiyyah (Demak: Panitia Perayaan Seabad Pondok Pesantren Futuhiyyah Mranggen Demak, 2001), 43.

12Ibid., 3.

13Ibid., 15, 44.

${ }^{14}$ Martin van Bruinessen, "Muslih b. 'Abd al-Rahman al-Maraqi: K.H. Muslikh of Mranggen," in Dictionnaire Biographique des Savants et Grandes Figures du Monde Musulman Périphérique, du XIXe Siècle a Nos Jours (Paris: CNRS-EHESS, 1988), 23-4.

${ }^{15}$ Usage of the word kyai is rather problematic for the Javanese people. It designates all things honoured, ranging from heirlooms, Islamic leaders, mystical leaders, and fortune tellers, to the buffaloes of the Javanese court. 
during his life in Mecca. ${ }^{16}$ Unfortunately these sources do not offer any information on the duration of his studies in Mecca. Probably van Bruinessen means that Muslih did not study in Mecca for a long period, as was common for his contemporaries.

Muslih wrote a number of books, primarily about Sufism. One of his works which does not deal with Sufism is Sullam alsibyan fi tarjamah bidāyah al-wildān, which is a Javanese translation of the Arabic book on nahw (Arabic grammar). The other is Inārah al-zalàm fì 'aqa'id al-'awwäm, which can be placed in the realm of Islamic theology. In addition, he wrote a popular treatise entitled Fadhilah Sholawat (The virtue of Șalawät ${ }^{17}$ ).

The Ikilab Risalab Tuntunan Tariqah Qadiriyah wa Naqshbandiyab (The Treatise on the Guidance of the TQN) is a practical introduction to the TQN. The more elaborate doctrine of the TQN is described in his other books, like 'Umdat al-sälik fi khayr al-masalik. (The Mainstay for the Seeker concerning the Best Spiritual Paths) and al-Futūhät al-rabbäniyyah fi al-tariqah alqädiriyyah wa al-naqshbandiyyah (Divine Insights concerning the TQN). He wrote some treatises such as Munäjät Qädiriyyah wa Naqshbandiyyah wa ad'ìatubā (on meditations and supplications recited mainly by the adherents of the TQN) and Wașa'il wușül al-'abd ila mawlāh bi shark al-tadallì min al-Lläh (which explains the aphorisms of the Alexandrian Sufi Tàj al-Dīn Abū al-Faḍl Aḥmad ibn Muḥammad ibn 'Ațā' Allāh al-Iskandarī, d. 1309). He also wrote a hagiography of 'Abd al-Qādir al-Jīlanī, namely al-Nūr al-burbānì fì tarjamat al-lujayn al-dāni fì dhikr nubdha min manäqib al-shaykeh' 'Abd al-Qädir al-jìlani.

It is through 'Abd al-Karim down to Asnawi Caringin (d. 1937) and finally 'Abd al-Latif ibn Ali Cilegon that Muslih

${ }^{16}$ See for example: Mranggen, Sejarah Seabad, 44., and Muhammad Ṣiddiq al-Sālihī, Risālah al-Iqyān fì Dhiker Silsilah Abl al-Trfān wa Bayān Mabnā A'māl Tarāiq Abl al-Iyān (Kudus: Jam‘ìyat Țarīqah al-Qādiriyyah wa alNaqshbandiyyah Manbā‘ al-Falāh), 296-300, 24-30.

${ }^{17}$ The salawàt (singular: șaläh) in this context connotes the supplications meant to call down blessings upon the Prophet Muhammad J. Spencer Trimingham, The Sufi Orders in Islam (Oxford: Oxford University Press, 1978), 310. 
gained the authority for teaching the TQN. Muslih is considered the most prominent khalifa of "Abd al-Latif. ${ }^{18} \mathrm{He}$ also drew his silsila from other directions, that is, 'Abd al-Rahman al-Mannuri, Ibrahim Yahya and 'Abd al-Karim Banten. ${ }^{19}$ Muslih referred to this later silsila as "min qibali shaykhina al-maräq" of our Master in Mranggen), as the two teachers, namely Ibrahim Yahya and Abd al-Rahman al-Mannuri, were from Mranggen. Indeed, Mranggen is one important locus for the initial growth of the TQN.

In the case of Mranggen, it is quite obvious that Muslih cannot be considered the pioneer of the TQN in this particular area. There was Ibrahim Yahya who initiated the propagation of the TQN in this area. All centres of the TQN in this area are usually attached to Ibrahim Yahya. We can name some of the most prominent students of this sheikh, namely 'Abd al-Rahman al-Mannuri (who spread the TQN in his own village, Menur, Mranggen) and 'Abd al-Rahman ibn Qasid al-Haqq (who spread the TQN in his own pesantren in Suburan, Mranggen).

It is also quite apparent that Muslih is not the one who forged the TQN in his pesantren. His father, 'Abd al-Rahman ibn Qasid al-Haq, and his older brother Uthman had taught the TQN in the pesantren. ${ }^{21}$ It is narrated that Muslih also drew the silsilah from his father, 'Abd al-Rahman ibn Qasid al-Haq.22 Muslih is considered to be the one who developed the TQN until it had gained a large membership, not only in this particular area but also throughout the Archipelago. Muslih succeeded his older brother as the leader of the pesantren (1936-1981), during which time he disseminated the TQN. The TQN under the leadership of Muslih is considered to be the golden age of the TQN of Mranggen. This is due to the belief of a number of people that he was a saint of God.

${ }^{18}$ Bruinessen, Tarekat Naqsyabandiyah, 93-4.

${ }^{19}$ Muslih ibn 'Abd al-Rahman al-Maraqi, Umdat al-Sälike fi Khayr alMasälik (Purworejo: Ma'had Berjan, n.d.), 142-8.

20ibid., 147.

${ }^{21}$ Mranggen, Sejarah Seabad, 7, 12, 4, 35.

22al-Sālihịi, Risälab al-Iqyān, 296. 
Muslih assigned a large number of khalifas which were of importance for the spread of the TQN. Ahmad Mutahhar ibn 'Abd al-Rahman ibn Qasid al-Haqq, M.S. Lutfi al-Hakim ibn Muslih, Muhammad Ridwan, and 'Abd al-Rahman ibn Ahmad Badawi were among his khalifas in Mranggen, who were entrusted to lead the communal recollection of God's names (tawajjuban) and to initiate the candidates after his death. ${ }^{23}$

Syafi'i makes a point of the fact that when Muslih died, his son-in-law 'Abd al-Rahman ibn Ahmad Badawi succeeded him as the leader of TQN because his two own sons, M.S. Lutfi alHakim (d. 2004) and Muhammad Hanif, were still too young. ${ }^{24}$ The khalifas of Muslih scattered in some parts of Java, West Kalimantan, West Nusa Tenggara, and Riau. It is due to these facts that Muslih is regarded as being ab al-mashayikh (the father of masters) or shaykh al-murshidin (the teacher of masters). ${ }^{25}$

Nowadays the TQN in Mranggen at least can be found in some pesantrens, most notably the Pesantren Futuhiyyah Mranggen, Ibrahimiyah Brumbung, al-Sharifah Brumbung ${ }^{26}$, alRahmaniyah Menur, and the Miftah al-'Ulum Ngemplak. ${ }^{27}$

23Mranggen, Sejarab Seabad, 55, 65.

${ }^{24}$ Bruinessen, "Muslih b.," 21-2. This might be true, since another source mentions that it was a couple of months after the death of Muslih that M.S. Lutfi al-Hakim found the letter of the appointment as murshid. Muslih told one of his disciples that he had left a letter for M.S. Lutfi alHakim in al-Ghazālī's Ihyà' 'ulüm al-dìn (Reviving the Religious Sciences). Muslih said that whenever M.S. Lutfi al-Hakim read this part of the book, he would find the letter, and it was the time for him to become a murshid. Still we have two suppositions. The first is that it was Abd al-Rahman Badawi who succeeded to the leadership of Muslih before it was transferred to M.S. Lutfi al-Hakim. The second is that there was a vacuum of leadership for a couple of months before M.S. Lutfi al-Hakim discovered Muslih's letter.

25Kholison Syafi'i, "Menjaga Kemurnian Kitab Kuning dengan Makna Gandul: KH. Muslih Abdurrahman Al-Maraqi," Al-Itqon 2 (2007): 13.

${ }^{26}$ The leader of the TQN in the Pesantren al-Sharifah obtained his ijaza from Ihsan Yahya, who was the khalifa of Ibrahim Yahya of the Pesantren Ibrahimiyah.

${ }^{27}$ The leader of the TQN in the Pesantren Miftah al-'Ulum possesses two silsilas, both of them ending with Ibrahim Yahya. The first lineage he derived from Ihsan Yahya, the khalifa of Ibrahim Yahya. The second one he 
Among these pesantrens, the Futuhiyyah is considered to be one which attracts a large membership.

Muhammad Hanif has been the current principal leader of the pesantren and the TQN since the death of his brother, M.S. Lutfi al-Hakim in 2004. Muhammad Hanif, Ahmad Sa'id Lafif ibn M.S. Lutfi al-Hakim, Abd al-Hadi ibn Ahmad Mutahhar ibn 'Abd al-Rahman al-Maraqi and Ahmad Zayn ibn Ahmad Mutahhar have been entrusted to lead the tawajjuban and initiate the candidates into the TQN of the Pesantren Futuhiyyah Mranggen. All these leaders received their ijäza from Ahmad Mutahhar, except Ahmad Sa'id Lafif ibn M.S. Lutfi al-Hakim, who received his ijąa from his father, M.S. Lutfi al-Hakim. Among these four leaders, Muhammad Hanif ibn Muslih and Ahmad Sa'id Lafif ibn M.S. Lutfi al-Hakim are considered as the main leaders.

\section{Popular piety and the veneration towards spiritual leaders}

Piety refers to the "manifestations of religious feelings and behaviour that, it seems to us, revolved around two impulses. The first of these is the need for purity, for a feeling of spiritual perfection, which comes from separating oneself from material and carnal thoughts and acts. The second component of piety is the feeling of reverence, the emotions of love, awe and fear that believers direct toward divinity and its attributes". 28

Weinstein and Bell point out that the notion of "popular piety" designates "more or less spontaneous, at least partly autonomous, religious ideas and impulses of men and women who were neither sophisticated doctrinalists nor members of the upper echelon of the clerical hierarchy". ${ }^{29}$ In line with this, Jacobs conceives popular piety as "popular expression of faith" which is not "sanctioned by the church" or, in other words, not

drew from Mashkuri ibn 'Abd al-Rahman, who obtained the ijaza from his father 'Abd al-Rahman al-Mannuri, the khalifa of Ibrahim Yahya.

${ }^{28}$ Donald and Rudolph M. Bell Weinstein, Saints and Society: The Two Worlds of Western Christendom, 1000-1700 (Chicago: Chicago University Press, 1986), 4.

29Ibid., 5. 
associated with liturgy. ${ }^{30}$ This piety often involves "practices of invocation and veneration" most specifically to the saintly figures. ${ }^{31}$

In the context of Christian societies, popular piety is embodied for instance, in the cult of saints. Weinstein and Bell explain the interplays between the cult of saints and popular piety in the following words:

The cult of saints illustrates perfectly how piety embraced the pursuit of spiritual perfection, the feeling of reverence, and the expectation of divine help in this world. ...the common conception linked all three and held that God bestowed supernatural power upon those who had achieved a high spiritual state. But the chasm between the saint's quest for an other-worldly perfection and the crowd's thirst for this-worldly miracles was bridged only imperfectly by medieval dialectic. Venerated for their holiness but invoked for their power, saints stood as reproach to the wonders-seeking crowd even as they served its humble needs. ${ }^{32}$

Jacobs depicts popular piety in Italia during the fifteenth and sixteenth century and puts this in the following words: "Devotees are described as weeping, beating their breasts, wailing, and removing whatever they wore that was of value rings, shawls, cloaks - and placing these things beside an image perceived to be, as one such painting in the Cathedral of Cremona was characterized, particularly apt to heal all ills." 33

In the context of Muslim societies, popular piety is often associated with the religious ideas and impulses of the lay people. Saints or Sufis often become the focal point of popular piety. These personages often serve as alternatives to the type of piety which is promoted by the Muslim jurists (faqihs).

Emil's study on the Egyptian Sufi Poet 'Umar ibn al-Farid (1181-1235) clearly demonstrates the linkage between Sufism and popular piety, as he notes that "Ibn al-Farid flourished in Egypt in the 12th to 13th centuries, when Sufi brotherhoods

${ }^{30}$ Fredrika H. Jacobs, Votive Panels and Popular Piety (Cambridge: Cambridge University Press, 2013), 18-20.

31Ibid., 61.

32Weinstein, Saints and Society, 7.

33 Jacobs, Votive Panels, 28. 
were taking on strongly institutionalised forms and saint shrines were becoming key foci of popular piety". ${ }^{34}$

Kinsley points out that the Sufi brotherhoods constitute "devotional communities", namely "groups formed primarily as a result of, or in order to cultivate, devotion". Most specifically, these brotherhoods are considered to be instances of "structured devotional communities" due to the fact that in these orders "devotion serves as a central role". ${ }^{35}$ In this vein, piety is highly observed within the Sufi orders. Grath points out that within the Sufism, features of piety persist "in more concerted and structured form". This mystical tendency within Islam rejects both "worldly compromise and doctrinal formalism within Islam". 36

Rule of conducts towards Sufi masters underlines and is grounded in "a wider web of practices and beliefs". This web renders meaning to all relations in a given community. ${ }^{37}$ One may say therefore that understanding saints or Sufi masters help us to understand piety, or more precisely, popular piety, and this comprehension will lead us to our better understanding of society. In this vein, we may perceive "religion as social product". 38

The veneration of the members towards the leaders within the Sufi orders often manifest in the festivals and rituals which demonstrate the popular piety associated with the orders and the surrounding societies. It is believed that the charisma of the saints or Sufi masters contributes to the solidity and the sustainability of the order. People venerate the Sufi masters during their lifetimes and after their decease. This veneration is

34Homerin Th. Emil, From Arab Poet to Muslim Saint: Ibn al-Farid, his Verse, and his Shrine (Columbia SC: University of South Carolina Press, 1994), 1-2.

35David Kinsley, "Devotion," The Encyclopedia of Religion: (Leiden: Brill, 1995), III \& IV, 323.

36Kenneth Grath, "Worship and Cultic Life: Muslim Worship," ibid.: (Leiden: E.J. Brill, 1995), XV \& XVI, 460.

${ }^{37}$ Asfa Widiyanto, Religious Authority and the Prospects for Religious Pluralism in Indonesia: The Role of Traditionalist Muslim Scholars (Berlin and Zürich: LIT Verlag, 2016), 15.

38Weinstein, Saints and Society, 7. 
linked to the code of conducts, which is grounded on "web of beliefs and practices" of the society in question.

\section{The code of conduct towards the master in the circle of the Tariqa Qadiriyya wa Naqsbandiyya}

In order to grasp more readily the code of conduct towards the master which has developed in the TQN in Mranggen, Central Java, I allude to Muslih's explanation pertaining to this rule of conduct. This code of conduct includes the following rules:

(1) "The disciple should hold the conviction that he will not arrive at the goal without the assistance of the master. He may not have the wish to change his master or look for another master, since it will hinder him from the reception of the flow of God's grace (al-fayd al-rahmāni). Shoud he so desire, he must first ask consent from the master. He may look for another master if he finds that his master has violated the prescriptions of Islamic law". 39

One practitioner stated that he had observed the practices of the TQN for a couple of years under a particular master. One day his father asked him to join another tariqah and recommended that he ask permission of the former sheikh prior to joining. This practitioner then asked the consent of the former sheikh, and fortunately the former sheikh allowed him to join another tariqah. The disciple observed both the practices of the TQN and of another tariqah, even until he was appointed khalifa of the latter tariqah.

In the history of the TQN in Indonesia, we notice the phenomenon of mass changes of master. A number of adherents of the TQN left their former master, since this master was affiliated to a political party, which was uncommon in the circle of pesantren and tarigah at that time. The opponents of this master claimed that it was a case of an "invalid chain of spiritual authorities", as a reason for this change of master. This reason

39al-Maraqi, Umdat al-Sälik, 33-4. 
was more acceptable in the circle of tariqah than that of affiliation to a political party. ${ }^{40}$

(2). "The disciple must not to be in a hurry to interpret dreams or other indications, even if he is smarter than the master. He is to tell them to his master, and to wait patiently for the answer. Even if the master does not provide the answer, the disciple has to be silent. He has to be convinced that there will always be a good purpose and secret wisdom behind the master's actions". ${ }^{41}$

Classic Sufi literature mentions the transparency that the disciple should maintain before his master. Al-Qushayrī, for instance, suggests that the disciple should not hide anything, not even the slightest concern or thought. The master is believed to possess a special keenness of sight (firasa), on whether the disciple's thoughts, dreams, and visions originate from Satan or from God. ${ }^{42}$ In other words, such transparency helps lessen the possibility that the disciple will go astray while on the spiritual path.

(3). "The disciple is to be humble before the master, for instance in a meeting held by the master. He is not to raise many questions or start a discussion. If he does so, it is a sign of bad manners, which may lead him to become hindered from spiritual development". 43

The teacher-disciple relationship in Islamic mystical tradition accentuates the obedience of the disciple to the master, which is considered able to trigger the flow of God's blessing (musabbib al-baraka). At such a point, curiosity and critical thought are not encouraged, since spiritual experiences are inaccessible to human reason alone.

${ }^{40}$ For further discussion on this particular issue, please see: Endang Turmudi, Struggling for the Umma: Changing Leadership of Kiai in Jombang, East Java (Canberra: ANU Press, 2006).

41al-Maraqi, Umdat al-Sälik, 35.

${ }^{42}$ Margaret Malamud, "Sufi Organizations and Structures of Authority in Medieval Nishapur," Int. J. Middle East Stud 26 (1994): 434.

43al-Maraqi, Umdat al-Sälik, 35. A similar tone, on the impact of having bad manners, can be observed in Muhammad ibn 'Abd Allāh al-Khānī, alBabjat al-Saniyyah fi Adab al-Tariqah al-'Aliyyah al-Khälidiyyah al-Naqshbandiyyah (Istanbul: Išik Kitabevi, 1977), 24. 
(4). "The disciple is not to come to the house of the master unscheduled. Instead he has to inquire from the master which time suits him prior to a visit. It is stressed that maintaining bad manners will hinder the disciple from the disclosure of wisdom and knowledge". ${ }^{44}$

The notion of unveiling wisdom and knowledge has become the key term in the circle of Sufism and the pesantren. It is widely held that the disciples' mastery of religious doctrines and knowledge is to some extent contingent on the disclosure granted by God (besides their own rational capacity).

(5). "If the disciple wishes to pass on the sayings of his master to someone else, he has to consider the spiritual preparedness of the recipient. He also has to consider which sayings are permitted by his master to be conveyed to others". ${ }^{45}$

One leader of the TQN, Ahmad Zain ibn Ahmad Mutahhar, asserted that the disciple is not to reveal to other persons the teachings of his master, particularly those pertaining to spiritual reality (baqiqa). ${ }^{46}$ Another leader of the TQN, Wahab Mahfudhi, ${ }^{47}$ explained that one needs a silsila prior to disseminating and teaching the doctrines of the tariqah.

An obvious message is that no one can claim to be able to teach the doctrines of the tariqah, even if he has mastered the theoretical aspects of the tariqah, before he obtains permission from an authoritative teacher. Even if he has obtained permission, he has to consider the readiness and the level of his disciples. The disciples should do the same: they are not to explain things to others, even to fellow disciples, if they deem (in their own opinion) this particular doctrine to be inappropriate. A disciple has likewise to consider which sayings are permitted by his master to be conveyed to others. It is believed by the Sufis that conveying the teachings of the tariqah to those unprepared is comparable to putting poison into their souls.

44al-Maraqi, Umdat al-Sälike, 36.

45Ibid., 37.

46Interview with Ahmad Zain ibn Ahmad Mutahhar, January 15, 2009.

${ }^{47}$ Interview with Wahab Mahfudhi, January 19, 2009. 
(6). "The disciple has to adopt an attitude of sincerity and maintain his love for the master. If the master passes away, the disciple may not marry his widow. He may marry the daughter of his master with the intention of rendering a service (khidma) to the master". ${ }^{48}$

One may have an impression that this sort of etiquette is comparable to that of the companions in relation to the Prophet. However, this does not fall into the category of a religious obligation, since we do not find any supporting religious text, but the suggestion of not marrying the widow of the master is still valuable as the disciple's proof of veneration to his master. The notion of khidma (rendering a valuable service) to the master still constitutes one of the key terms in these codes of conduct. This notion includes a service that a client should render to the patron.

(7). "The disciple has to be compassionate to the children of his master and treat them like his brothers and sisters as evidence of his reverence for the master, since the master is essentially his spiritual father". ${ }^{49}$

In Sufi literature, discipleship is often referred to as "spiritual birth" (al-wilada al-ma'nawiyya),"50 because during this period the soul is left in an immature state and blossoms under the supervision of the master. The term "spiritual father" (ab ma nawn) for the teacher is also used by such medieval Islamic thinkers as Ikhwān al-Ṣafā'. ${ }^{1}$ The notion of "spiritual father" extends beyond the boundaries of the Islamic mystical tradition.

The Naqshbandī scholar Muhammad ibn 'Abd Allāh alKhānī (d. 1899) prescribes a number of conditions (sharä'ịt) to

48al-Maraqi, Umdat al-Sälike, 39.

${ }^{49}$ Ibid.

${ }^{50}$ Malamud, "Sufi Organizations," 95.

51'Umar al-Dasūqī, Ikhwān al-Safä’ (Cairo: Dār al-Kutub al-'Arabiyyah, n.d.), 207. The Ikbwain al-safä' is a group of philosophers who lived around the fourth century bijriyya in Basrah. See: Ian Richard Netton, "The Brethren of Purity: Ikhwān al-Ṣālfāa," in History of Islamic Philosophy, ed. Seyyed Hossein Nasr and Oliver Leaman (London: Routledge, 1996). See also: Y. Marquet, "Ikhwān al-Ṣafā'," The Encyclopaedia of Islam: New Edition (Leiden: E.J. Brill, 1993), III, 1071. 
be followed by the disciple. In one of these conditions, he mentions that the disciple should not question his master's deeds even in his heart. Al-Khānī refers to the story of the prophet Khiḍr ${ }^{52}$ and the prophet Mùsā, to underline the obedience of the disciple towards his master. ${ }^{53}$ The story of Khidr (in addition to the story of the encounters of the companions with the prophet Muhammad) has become a prototype of the relationship between the disciple and the master in the circle of the tariqah. What is being underlined in this story is such qualities as complete obedience, trust, positive thinking and humility.

The figure of Khidr is often employed to stress the fullest reverence and the positive thinking regarding another person. Al-Khānī, for instance, states that a disciple is not to view another person negatively, but should consider him as Khiḍr or a saint. Al-Khānî likewise hints that the disciple is to see himself as the lowest being. ${ }^{54}$ In the Sufi point of view, learning to have positive thinking for the master is a step towards positive thinking for other creatures and, above all, for God.

The Sufi authors often accentuate the necessity for obedience, humility (even thinking of oneself as the lowest being) and thinking positively about others as prerequisites for obtaining the flow of God's blessing which could otherwise not be encountered through rationality alone. Seen from another angle, such qualities can be considered to mean "controlling" or "postponing" one's ego and rationality, in order to provide a space for the activation of another capacity, namely intuition or the eye of the heart, which is of importance for the perfection of one's spirituality.

The Naqshbandī scholar Aḥmad Diyā' al-Dīn Gümüṣhaneli describes a code of behaviours to be applied by the disciple

52The prophet Khidr is often considered the prototypical saint (See, Trimingham, The Sufi Orders, 224.) The figure of Khidr is central in Sufism, and accordingly one Sufi author used the name of this figure as the title of his book ('Abd al-Wahhāb al-Sha'rānī al-Mì̄ann al-Khidhriyyah (Egypt: 'Ālam al-Fikr, 1989).

53al-Khānī, al-Babjat al-Saniyyah, 24.

54Ibid., 25. 
towards his master. ${ }^{55}$ Another Naqshbandī scholar, al-Khānī, has created a set of rules of conduct to be observed by the disciple towards his master: he states that there are fifteen modes of conduct which the majority of the Sufis adhere to. ${ }^{56}$ When we look at these rules, we become aware that there is an affinity between al-Khānī's and Muslih's explanations. This includes at least two possibilities. First, Muslih has cited some of his explanations from al-Khānī and other authors. Secondly, Muslih quoted some of his explanations from other authors (which in some ways conform to the explanation of al-Khānî), since most of these rules of conduct had already been agreed upon by most Sufis. Al-Khānī himself, in his explanation on these kinds of conduct, alludes to al-Nafakhat al-qudsiyya by 'Abd al-Wahhāb ibn Aḥmad al-Sha'rānī.

This set of rules of conduct (that the disciple should observe towards the master) is therefore not exclusive to the TQN. We come across a parallel set of codes in the Qādiriyya, for instance in 'Abd al-Qādir al-Jīlanì's al-Gbunyah li țälibì taríq al-Haqq 'azza wa jalla. ${ }^{57}$ We can likewise encounter a comparable set of norms in the writings of Naqshbandī authors such as Gümüshaneli and al-Khānī. This code has much in common with the one offered by the Sufi author al-Sha'rānī. A glance at the works of the leaders of the TQN shows a high degree of receptiveness to the ideas of al-Sha'rānī (including his ideas on codes of conduct in the tariqab).

The set of codes of conduct in the TQN is in some ways connected to those in the pesantren, which to some extent has been moulded by the Ta'lim al-muta allim. ${ }^{58}$ One of the apparent

${ }^{55}$ Aḥmad Diyā' al-Dīn Gümüṣhaneli, Jāmi` al-Usūl fi al-Awliyyà' (Cairo: Maṭba'ah al-Jamaliyyah), 54.

56al-Khānī, al-Bahjat al-Saniyyah, 25-6.

${ }^{57} \mathrm{Abd}$ al-Qādir al-Jīlānī, al-Gunyah li Ṭälibì Ṭariq al-Haqq 'Azża wa Jalla (n.p., 2006), 557-63.

${ }^{58}$ Ta'lim al-Muta'allim: Tariq al-Ta'allum (Instruction of the Student: the Method of Learning) is a work composed by Burhān al-Dīn al-Zarkashī (d.1223) (See: E von and Theodora M. Abel Grunebaum, ed. Ta'tim alMuta'allim: Tariq al-Ta'allum (Instruction of the Student: the Method of Learning) (New York: King's Crown Pr, 1947). On the nature of the interaction between student and teacher. The ideas contained in this particular work are 
notions that we can observe in the circle of pesantren is khidma (rendering a valuable service to the master). This may be seen as a sort of patron-client relationship, if we wish to employ different terminology.

The attraction of Muslih's personality in some ways determines the nature of these codes and the way in which they are implemented in the area of Mranggen in particular and Central Java in general. How the codes of conduct are implemented is unique. These codes are supported by the idea of sainthood and traditional Javanese patronage.

Paul claims that the interaction between sheikh and disciple constitutes a keystone of Sufi organisation. ${ }^{59}$ In the course of the eleventh century, there was an increasing attention to codes of conduct that were meant to regulate interaction between masters and disciples. A master was considered an example for the disciple, and accordingly emulating his behaviour was encouraged. Emulation of a master was (and is) regarded as a precondition for the disciple's inner transformation. ${ }^{60}$

Sufi training aims to replace the "self-will" with the "divinewill". Learning under the will of the master is considered as the first step in learning to surrender to the will of God. Utter submission to the master is believed to bring the adherent closer to this end. ${ }^{61}$ The codes of conduct which the disciple should maintain before his master are seen as promoting this aim.

In Sufi circles, surrendering to the will of the master is of significance for the spiritual transmutation of the disciple. This is due to the conviction that power and authority are in the possession of the master, and it is through acts of submission that a disciple can accomplish spiritual ripeness and power. ${ }^{62}$

relatively well accepted in the circle of pesantren, and accordingly contribute to moulding the mode of relationship between the student and the teacher.

59Jürgen Paul, Doctrine and Organization: the Khwajagan/Naqshbandiya in the First Generation after Baha' al-Din (Berlin: Das arabische Buch-Verlag, 1988), 53.

${ }^{60}$ Malamud, "Sufi Organizations," 435.

${ }^{61}$ Ibid., 434.

62Margaret Malamud, "Gender and Spiritual Self-Fashioning: the Master-Disciple Relationship in Classical Sufism," Journal of the American Academy of Religion 64, no. 1 (1996): 108. 
One leader of the TQN, Maksum Mahfudhi, related that he had a meeting with his master pertaining to his appointment as khalifa. He insisted on going to see the sheikh, even though a member of his family has just passed away. ${ }^{63}$ Another leader of the TQN, Mashkuri ibn 'Abd al-Rahman, made a parable of the flow of God's grace (al-fayd al-rahmani) with the flow of water in the rain gutter. A disciple has to place himself below the sheikh, or in other words observe a code of conduct in order to enable his blessing to flow. ${ }^{64}$

\section{Celebration of the leaders' deaths anniversary in the circle of the Tariqa Qadiriyya wa Naqsbandiyya}

In the Muslim world, the festivity venerating the death of a leader is frequently termed hawliyya. In Indian subcontinent, this sort of festival is termed as 'urs (wedding), since the death of a saint is considered to be the moment of his encounter with God. ${ }^{65}$ Philippon points out that "in a mystical perspective, this points to his union with God and hence his true birth, providing the occasion for a popular yearly pilgrimage that bestows his identity and authority onto a shrine and delineates his mediatory power in relation to God". 66

This festivity is known as hawl to Indonesian Muslims. In the Muslim world, we also encounter a celebration of a leader's birth (mawlid). ${ }^{67}$ It is worth remarking the birth anniversary is less familiar than the death anniversary in the Muslim society, in general, and the circle of tarigah, in particular. There is reasoning for the preference of death anniversary over birth anniversary in the tariqah, namely that the Sufis accentuate on thinking about death. The second reasoning is that the Muslims' veneration of the Sufis continues after their death. These Sufis are believed to sustain as the holders of baraka even after their deaths. The third

63Interview with Ma'sum Mahfudhi, January 4, 2009.

64Interview with Mashkuri ibn 'Abd al-Rahman, January 7, 2009.

65Trimingham, The Sufi Orders, 178, 80, 313.

${ }^{66}$ Alix Philippon, "The 'urs of the Patron Saint of Lahore: National Popular Festival and Sacred Union between the Pakistani State and Society?," Social Compass 59, no. 3 (2012): 292.

67'Trimingham, The Sufi Orders, 180. 
reasoning is that the shrines of the Sufis attract a number of visitors and consequently become the foci of popular piety.

In this regard we may see that the Muslims prefer to celebrate the death anniversary of their Sufi leaders rather than their birth anniversary. In contrast to their position towards the Sufi masters, Muslim society favours to celebrate the birth anniversary of the Prophet rather than his death anniversary. This seems to be based on some reasoning. First, the Muslims underline the living prophetic values that were brought by the Prophet. Second, the Prophet's birth anniversary signifies his presence and his significance for the betterment of the world. Third, the Prophet's birth anniversary serves to stimulate the motivation and spirit of the Muslims so as to enhance their position and to defend their dignity. In the Islamic history, we see that the founder of Ayyubia dynasty Ṣalāh al-Dīn Yūsuf ibn Ayyūb (1137-1193) promoted the celebration of the Prophet's birth so as to awake the spirits of the Muslims in their struggle against the Crusaders.

In many parts of the Muslim world, we encounter the practices of devotion to the saint, which are sometimes designated as "saint-worship". This kind of devotion includes such practices as visits to the shrine of the saint and celebration of the saint's death anniversary. The magnitude of the commemoration is tied to spiritual accomplishments of the saint and his genealogical eminence. The saint's death anniversary offers an opportunity for the Sufi families to meet their followers, enjoy their generosity and render spiritual advice. ${ }^{68}$ The shrines of the saints attract the attention of the people, since they believe that these saints continue to grant the wishes and to transmit the baraka. These shrines represent the specimens of a cult towards saints. These shrines are taken care by Sufi families and or neighbourhood people. ${ }^{69}$ During the saint's death anniversary, these shrines attract more visitors than the normal days.

${ }^{68}$ P. van der Veer, "Playing or Praying: A Sufi Saint's Day in Surat," Journal of Asian Studies 51, no. 3 (1992): 546-52.

${ }^{69}$ Ibid., 546-9. 
In Mranggen, Demak, Central Java, we come across at least three outstanding events of commemorating the leaders' death anniversary. These festivities include: (a) the hawliyya of Ibrahim Yahya which takes place in the Pesantren Ibrahimiyah Brumbung; (b) the hawliyya of 'Abd al-Rahman ibn Qasid alHaqq al-Maraqi which takes places in the Pesantren Futuhiyyah Mranggen; and (c) the hawliyya of 'Abd al-Rahman al-Mannuri which is held in the Pesantren Rahmaniyah Menur.

At the occasion of the hawliyya of Ibrahim Yahya, his hagiography (manaqib) $)^{70}$ is narrated orally. This festivity takes place at the Pesantren Ibrahimiyah. It was Muslih who was asked to narrate this story. Nevertheless, we do come across any written hagiography about Muslih, although he was and is revered in the circle of the TQN, most particularly in Central Java.

This is probably due to the Muslih's veneration towards his master, Ibrahim Yahya. Revering the master, during his life or after his death, constitutes a significant feature of the rules of conduct in the circle of pesantren and tariqah. This likewise holds true for the case of the celebration of death anniversary. Muslih is reported to have urged that the people should not hold any special hawliyya for him. He would prefer to be incorporated in the ḩawliyya of his father, 'Abd al-Rahman ibn Qasid al-Haqq alMaraqi.

This festivity draws the attention of the large number of people, either from the followers of the TQN or from Muslim neighbourhood in general. A great number of students and teachers of the Pesantren Futuhiyah usually attend the celebration, due to their reverence to Ibrahim Yahya, who happened to be the teacher of Muslih.

${ }^{70}$ For further discussion on the manaqib genre in the circle of the Tariqa Qadiriyya wa Naqshbandiyya, most particularly which has been developed by Muḥammad Șiddīq al-Ṣalihī (d. 2009), please see: Asfa Widiyanto, "Manaqib Writing in the Circle of the Tariqa Qadiriyya wa Naqshbandiyya: A Study on Muhammad Șiddīq al-Ṣāliḥ̂̉s Nayl al-Amānī," Heritage of Nusantara: International Journal of Religious Literature and Heritage 4, no. 2 (2005): 213-42. 
One of the stories told in Ibrahim Yahya's hagiography is that once he, his students and some members of his family wanted to undertake a pilgrimage to Mecca. Reaching the harbour of Jakarta, the ship in which they were travelling caught fire. Most of the passengers panicked. Nonetheless, Ibrahim Yahya's disciple and family were able wait until he had completed his supererogatory morning prayer (saläh al-duha $)$. Having finished the prayer, Ibrahim Yahya asked what was going on. His son explained the matter to him. Ibrahim Yahya tried to calm the people by saying that the ship would soon be fine. Then he recited a supplication. Shortly after that the fire was extinguished. ${ }^{71}$

Another story recorded in this hagiography goes that, once a day, Muslih was visited by a sheikh who asked to be accompanied to visit the grave of Ibrahim Yahya. Muslih picked up the key at the Pesantren Ibrahimiyah and let the guest enter the grave complex. The guest entered the complex and greeted Ibrahim Yahya. Muslih was astounded that he could clearly hear the conversation between the guest and the spirit of Ibrahim Yahya. ${ }^{72}$

One sheikh of the TQN, Muhammad Hanif, contended that one of the aims of holding the hawliyya is to remind people of death and to remember the pious. ${ }^{73}$ According to prophetic tradition, "remembering the prophets is a part of devotion, recollecting the pious may lessen one's sins; thinking of death is alms; thinking about the grave can draw one closer to heaven". This hadith has likewise become part of the recitation of the hagiography, ${ }^{74}$ which is frequently read on the occasion of

${ }^{71}$ Rofiq Irzani, Manaqib Syeh KH. Ibrobim (Demak: Pondok Pesantren Ibrohimiyah, n.d.), 16.

72Ibid., 19.

73Interview with Muhammad Hanif, January 6, 2009.

${ }^{74}$ Manaquib (often translated as hagiography) is a genre of biographical works which possesses a distinctive feature, namely striving to reveal the merits, virtues and remarkable deeds of the person concerned. Accordingly, the manáqib may be called a laudatory biography. This genre is often employed to depict the lives of saints and other venerated figures. As far as they are concerned, with the saints or Sufis the manaqib normally attempts to bring out their miracles. The word manāqib, however, at times appears as a 
hawliyya. It is also employed as an argument for räbita, in particular the phrase "recollecting the pious may lessen one's sins". 75

One leader of the TQN, Ahmad Sa'id Lafif, asserted that there was no a special hawliyya for his late father (who was a descendant of 'Abd al-Rahman ibn Qasid al-Haqq al-Maraqi); instead it would be included in the framework of the hawliyya of the family of 'Abd al-Rahman ibn Qasid al-Haqq al-Maraqi in the Pesantren Futuhiyyah. Nonetheless, he did not prohibit the disciples, if there were any who wished to arrange a special hawliyya for his late father in their respective places. ${ }^{76}$

The bawliyya of 'Abd al-Rahman ibn Qasid al-Haqq alMaraqi, which is held at the Pesantren Futuhiyyah Mranggen, is begun with the reading of the Qur'an and lasts until midday prayer (zubr). The festivity goes on after the evening prayer (isha'), in which the $\operatorname{tablilan~}^{77}$ and the hagiography of 'Abd alQādir al-Jīlanī are recited. This celebration catches the attention of the large number of people, either from the followers of the TQN or the Muslim people in general. One may suppose that this is due to the charisma of Muslim, which becomes a magnet for the people attending the celebration.

The last hawliyya in Mranggen is that of 'Abd al-Rahman alMannuri. The festivity takes place at the Pesantren Rahmaniyah Menur. This celebration comprises of recitation of the Qur'anic verses, hearing Islamic teachings from the leaders of the TQN, visiting the shrines of the leaders, and reading the hagiography of al-Jīlanī. This celebration also attracts a large number of people, to attend the celebration. The followers of the TQN and the Muslim people from Mranggen and the adjacent areas come

title of a work describing a particular place (CH. Pellat, "Manāqib," The Encyclopaedia of Islam: New Edition (Leiden: E.J. Brill, 1991), VI, 349-57.

75See: al-Maraqi, Umdat al-Sälik, 54. See also Muslih ibn 'Abd alRahman al-Maraqi, al-Futūḥ̄t al-Rabbāniyyah fi al-Ṭariqah al-Qādiriyyah wa alNaqshbandiyyah (Semarang: Karya Toha Putra, 1994), 72.

76Interview with Ahmad Sa'id Lafif, January 9, 2009.

${ }^{77}$ The term tablilan derives from the Arabic word tablil, which means the recitation of "Là ilāha illä Ilāh" (there is no god but God). The term tablilan is usually applied to a list of prayers (of which the recitation of " $L \bar{a}$ ilahba illa lläh" is the centre), which is often recited for people who have died. 
to pay homage to al-Mannuri. The parents of the Pesantren Rahmaniyah's disciples usually come to and support this celebration.

The hagiography of al-jīlanī is likewise occasionally read at the communal ritual of the TQN. The recital of the hagiography, however, extends beyond the tradition of tariqah, let alone the TQN. One leader of the TQN, Muhammad Hanif, related that both the recital of the hagiography and the communal ritual of the tariqah aim at the same goal, namely hoping for the barakah of the saints and assistance from God. Many people are attracted to participate in the hawliyya since they believe that, "those who love the beloved are likewise loved". ${ }^{78}$ This corresponds to the saying of one Sufi, that "love of holiness is also a part of holiness". ${ }^{79}$

Some centres of the TQN (such as the Pesantren Manba' alFalah, Dawe, Kudus, Central Java) hold a monthly gathering on the eleventh of the Muslim calendar (bijriyya), in which the practitioners most commonly recite the hagiography of 'Abd alQādir al-Jīlanī. The gathering held on this particular date is found in particular in the Qàdiriyya. It corresponds with a range of festivities in honour of al-Jīlanī on 11 Rabi al-thāni (of the Muslim lunar calendar) in several places in the Muslim world. ${ }^{80}$ Another publication ${ }^{81}$ notes, however, that there are some other tariqabs (like the Rifā'iyya ${ }^{82}$ and the Shādhīliyya) which hold their monthly gathering on the eleventh.

78Interview with Muhammad Hanif, January 6, 2009.

${ }^{79}$ Fritz Meier, Zwei Abhandlungen über die Naqshbandiyya, I: Die Herzenbindungen an die Meister, II: Kraftakt und Faustrecht des Heiligen (Istanbul: Franz Steiner, 1994), 59.

80D.S. Margoliouth, "Qādiriyya," The Encyclopaedia of Islam: New Edition (Leiden: E.J. Brill, 1978), IV, 382.

${ }^{81}$ Syed Naquib al-Attas, Some Aspects of Sufism as Understood and Practised among the Malays (Singapore: n.p., 1963), 44.

${ }^{82}$ The Rifä iyya is a Sufi brotherhood which is named after its founder, the Iraqi Scholar Ahmmad ibn 'Alī al-Rifā'c- (d. 1182) (C.E. Bosworth, "Rifāiiyya," The Encyclopaedia of Islam: New Edition (Leiden: E.J. Brill, 1995), 525-6. 


\section{Concluding remarks}

A set of rules of conduct is usually prescribed by the master so as to govern the relationship between the disciple and the master. Such features as complete obedience, trust, positive thinking and humility constitute the most important parts of the codes of conduct towards the master. The code of conduct towards the masters of the TQN is observable for instance from Muslih's explanation pertaining to this rule. One of which includes a vindication that "the disciple should hold the conviction that he will not arrive at the goal without the assistance of the master".

Code of conducts towards Sufi masters underlines and is grounded in "a wider web of practices and beliefs", which renders meaning to all relations in a given community. In the context of the TQN in Mranggen, Central Java, this web of practices and beliefs includes the values of Javanese, Pesantren and Sufism.

This set of rules of conduct (that the disciple should observe towards the master) is therefore not exclusive to the TQN. We come across a parallel set of codes in the Qādiriyya, for instance in 'Abd al-Qādir al-Jīlanì's al-Gbunyah li țälibì tarì al-Haqq 'azza wa jalla. We can likewise encounter a comparable set of norms in the writings of Naqshbandī authors such as Gümüṣhaneli and al-Khānī. This code has much in common with the one offered by the Sufi author al-Sha'rānī. A glance at the works of the leaders of the TQN shows a high degree of receptiveness to the ideas of al-Sha'rānī (including his ideas on codes of conduct in the tariqab).

The set of codes of conduct in the TQN is in some ways connected to those in the pesantren, which to some extent has been moulded by the Ta'lim al-muta allim. One of the apparent notions that we can observe in the circle of pesantren is khidma (rendering a valuable service to the master). This may be seen as a sort of patron-client relationship, if we wish to employ different terminology.

Revering the master, during his life or after his death, constitutes a significant feature of the rules of conduct in the circle of pesantren and tariqah. This veneration manifests for 
instance in the case of the festivity commemorating the leaders' death. In the Muslim society, in general, and in the circle of the tariqa, the celebration of leaders' death anniversary is mostly termed hawliyya. In Indian subcontinent, this sort of festival is termed as 'urs (wedding), since the death of a saint is considered to be the moment of his encounter with God.

In Mranggen, Demak, Central Java, we come across at least three important events of commemorating the leaders' death anniversary. These festivities include: (a) the hawliyya of Ibrahim Yahya which takes place in the Pesantren Ibrahimiyah Brumbung; (b) the hawliyya of 'Abd al-Rahman ibn Qasid alHaqq al-Maraqi which is held in the Pesantren Futuhiyyah Mranggen; and (c) the hawliyya of 'Abd al-Rahman al-Mannuri which takes place in the Pesantren Rahmaniyah Menur.

The leader's death anniversary provides an opportunity for the Sufi families to meet their followers, enjoy their generosity and render spiritual advice. This festivity draws the attention of the large number of people, either from the followers of the TQN or from the Muslim society in general. A great number of students and parents usually attend and even support the celebration, due to their reverence to the leaders of the TQN and the pesantren.

The hagiography of 'Abd al-Qādir al-Jîlanī is likewise occasionally read at the communal ritual of the TQN. The recital of the hagiography, however, extends beyond the tradition of tariqah, let alone the TQN. Many people are attracted to participate in the hawliyya since they believe that, "those who love the beloved are likewise loved".

Code of conduct and leaders' death anniversary contribute to the moulding of popular piety within the Muslim community, in general, and among members of the TQN in particular. This piety is concerned with the religious ideas and impulses of the common people which are not associated with liturgy. Saints or Sufis often become the focal points of popular piety. These personages often serve as alternatives to the type of piety which is promoted by the Muslim jurists (faqibs). 


\section{References}

al-Attas, Syed Naquib. Some Aspects of Sufism as Understood and Practised among the Malays. Singapore: n.p., 1963.

al-Dasūqī, 'Umar. Ikhwān al-Ṣafă'. Cairo: Dār al-Kutub al'Arabiyyah, n.d.

al-Ghazālī, Abū Hāmid Muhammad ibn Muhammad. Ibyà' 'Ulūm al-Dìn. Vol. IV. Dār al-Fikr, n.d.

al-Jīlānī, 'Abd al-Qādir. al-Gunyah li Ṭälibì Ṭariq al-Haqq 'Arža wa Jalla. n.p., 2006.

al-Khānī, Muhammad ibn 'Abd Allāh. al-Babjat al-Saniyyah fì Adab al-Tariqah al-'Aliyyah al-Khälidiyyah al-Naqshbandiyyah. Istanbul: Išik Kitabevi, 1977.

al-Maraqi, Muslih ibn 'Abd al-Rahman. al-Futūhät al-Rabbāniyyah fi al-Ṭariqah al-Qädiriyyah wa al-Naqshbandiyyah. Semarang: Karya Toha Putra, 1994.

------. 'Umdat al-Sälike fī Khayr al-Masälik. Purworejo: Ma'had Berjan, n.d.

al-Sāliḥ̄, Muhammad Șiddiq. Risālah al-Iqyān fì Dhiker Silsilah Abl al-Irfän wa Bayān Mabnā A'mäl Tarāiq Abl al-'Tyān. Kudus: Jam‘ìyat Ṭarīqah al-Qādiriyyah wa al-Naqshbandiyyah Manbā' al-Falāh, n.d.

al-Sha'rānī , 'Abd al-Wahhāb. al-Mì̄àn al-Khidhriyyah. Egypt: 'Ālam al-Fikr, 1989.

Algar, Hamid. "Silent and Vocal Dhikr in the Naqshbandi Order." In Akten des VII Konggresses für Arabistik und Islamwissenschaft, 39-46. Göttingen: Vandenhoek \& Ruprecht, 1974.

Azra, Azyumardi. Jaringan Ulama Timur Tengab dan Kepulauan Nusantara Abad XVII \& XVIII: Akar Pembaharuan Islam Indonesia. Bandung: Mizan, 1996.

------. "Opposition to Sufism in the East Indies in the Seventeenth and Eighteenth Centuries." In Islamic Mysticism Contested: Thirteen Centuries of Controversies and Polemics, edited by Frederick de Jong and Bernd Radtke. Leiden: Brill, 1999.

--. The Origins of Islamic Reformism in Southeast Asia: Networks of Malay-Indonesian and Middle Eastern 'Ulama' in the Seventeenth and Eighteenth Century. Leiden: KITLV Press, 2004. 
Bosworth, C.E., "Rifāiiyya," The Encyclopaedia of Islam: New Edition (Leiden: E.J. Brill, 1995), 525-6.

Bruinessen, Martin van. Tarekat Naqsyabandiyah di Indonesia: Survei Historis, Geografis, dan Sosiologis. Bandung: Mizan, 1998.

Bruinessen, Martin van "Muslih b. 'Abd al-Rahman al-Maraqi: K.H. Muslikh of Mranggen." In Dictionnaire Biographique des Savants et Grandes Figures du Monde Musulman Périphérique, du XIXe Siècle a Nos Jours. Paris: CNRS-EHESS, 1988.

Emil, Homerin Th. From Arab Poet to Muslim Saint: Ibn al-Farid, his Verse, and his Shrine. Columbia SC: University of South Carolina Press, 1994.

Grath, Kenneth, "Worship and Cultic Life: Muslim Worship," The Encyclopedia of Religion: (Leiden: E.J. Brill, 1995), XV \& XVI.

Grunebaum, E von and Theodora M. Abel, ed. Ta'tim alMuta'allim: Tariq al-Ta'allum (Instruction of the Student: the Method of Learning). New York: King's Crown Pr, 1947.

Gümüṣhaneli, Aḥmad Diyā' al-Dīn. Jāmi al-Usūl fì al-Awliyāà. Cairo: Mațba'ah al-Jamaliyyah, 1910.

Irzani, Rofiq. Manaqib Syeh KH. Ibrobim. Demak: Pondok Pesantren Ibrohimiyah, n.d.

Jacobs, Fredrika H. Votive Panels and Popular Piety. Cambridge: Cambridge University Press, 2013.

Kinsley, David, "Devotion," The Encyclopedia of Religion: (Leiden: Brill, 1995), III \& IV.

Malamud, Margaret. "Sufi Organizations and Structures of Authority in Medieval Nishapur." Int. J. Middle East Stud 26 (1994): 427-42.

------. "Gender and Spiritual Self-Fashioning: the MasterDisciple Relationship in Classical Sufism." Journal of the American Academy of Religion 64, no. 1 (1996): 89-117.

Margoliouth, D.S., "Qādiriyya," The Encyclopaedia of Islam: New Edition (Leiden: E.J. Brill, 1978), IV, 380-3.

Marquet, Y., "Ikhwān al-Ṣafā'," The Encyclopaedia of Islam: New Edition (Leiden: E.J. Brill, 1993), III.

Meier, Fritz. Zwei Abhandlungen über die Naqshbandiyya, I: Die Herzenbindungen an die Meister, II: Kraftakt und Faustrecht des Heiligen. Istanbul: Franz Steiner, 1994. 
Mranggen, Team Peneliti Sejarah Seabad Ponpes Futuhiyyah. Sejarah Seabad Pondok Pesantren Futubiyyah. Demak: Panitia Perayaan Seabad Pondok Pesantren Futuhiyyah Mranggen Demak, 2001.

Munoz, Paul Michel. Early Kingdoms of the Indonesian Archipelago and the Malay Peninsula. Singapore: Editions Didier Millet, 2006.

Netton, Ian Richard. "The Brethren of Purity: Ikhwān al-Ṣālfā’." In History of Islamic Philosophy, edited by Seyyed Hossein Nasr and Oliver Leaman. London: Routledge, 1996.

Paul, Jürgen. Doctrine and Organization: the Khwajagan/Naqshbandiya in the First Generation after Baba' al-Din. Berlin: Das arabische Buch-Verlag, 1988.

Pellat, CH. , "Manāqib," The Encyclopaedia of Islam: New Edition (Leiden: E.J. Brill, 1991), VI, 349-57.

Philippon, Alix. "The 'urs of the Patron Saint of Lahore: National Popular Festival and Sacred Union between the Pakistani State and Society?" Social Compass 59, no. 3 (2012): 289-93.

Syafi'i, Kholison. "Menjaga Kemurnian Kitab Kuning dengan

Makna Gandul: KH. Muslih Abdurrahman Al-Maraqi." AlItqon 2 (2007).

Togan, Isenbike. "The Khafi Jahri Controversy in Central Asia

Revisited." In Naqshbandis in Western and Central Asia: Change and Continuity, edited by Elizabeth Ozdalga, 17-46. Istanbul: Swedish Research Institute in Istanbul, 1999.

Trimingham, J. Spencer. The Sufi Orders in Islam. Oxford: Oxford University Press, 1978.

Turmudi, Endang. Struggling for the Umma: Changing Leadership of Kiai in Jombang, East Java. Canberra: ANU Press, 2006.

Veer, P. van der. "Playing or Praying: A Sufi Saint's Day in Surat." Journal of Asian Studies 51, no. 3 (1992): 545-464.

Weinstein, Donald and Rudolph M. Bell. Saints and Society: The Two Worlds of Western Christendom, 1000-1700. Chicago: Chicago University Press, 1986.

Widiyanto, Asfa. "Manaqib Writing in the Circle of the Tariqa Qadiriyya wa Naqshbandiyya: A Study on Muhammad Ṣiddīq al-Ṣāliḥ̂’s Nayl al-Amānī." Heritage of Nusantara: 
292 Ulumunz, Vol. 20, No. 2 (December) 2016

International Journal of Religious Literature and Heritage 4, no. 2 (2005): 213-42.

------. Religious Authority and the Prospects for Religious Pluralism in Indonesia: The Role of Traditionalist Muslim Scholars. Berlin and Zürich: LIT Verlag, 2016.

Woodward, Mark R. Islam in Java: Normative Piety and Mysticism in the Sultanate of Yogyakarta. Tucson: The University of Arizona Press, 1989.

Zulkifli. Sufism in Java: The Role of the Pesantren in the Maintenance of Sufism in Java. Jakarta and Leiden: INIS, 2002. 